\title{
Toxicity evaluation of leached of sugarcane vinasse: Histopathology and immunostaining of cellular stress protein
}

\author{
Maria Paula Mancini Coelho ${ }^{\mathrm{a}}$, Jorge Evangelista Correia ${ }^{\mathrm{a}}$, Louise Idalgo Vasques ${ }^{\mathrm{a}}$, \\ Ana Claudia de Castro Marcato ${ }^{\mathrm{a}}$, Thays de Andrade Guedes ${ }^{\mathrm{a}}$, Miguel Alfaro Soto ${ }^{\mathrm{b}}$, \\ Juliana Broggio Basso ${ }^{\mathrm{b}}$, Chang Kiang ${ }^{\mathrm{b}}$, Carmem Silvia Fontanetti ${ }^{\mathrm{a}, *}$ \\ ${ }^{a}$ UNESP - São Paulo State University, IB (Instituto de Biociências), Av. 24-A, 1515, CEP: 13506-900 Rio Claro, São Paulo, Brazil

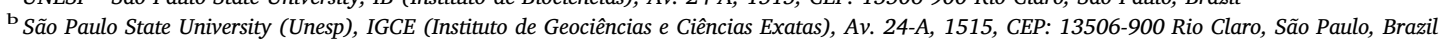

\section{A R T I C L E I N F O}

\section{Keywords:}

Aquatic toxicity

Gill

Liver

Histology

Immunohistochemical

\begin{abstract}
A B S T R A C T
Sugarcane vinasse is a residue generated at a rate fifteen times greater than the ethanol production. Because of its high organic and micronutrient content, this residue is used as a fertilizer on sugarcane crops. However, when used in large quantities, vinasse can saturate the soil and contaminate nearby water resources by percolation and leaching. Given the proven toxic potential of in natura vinasse, the present study aimed to evaluate the toxic potential of leached sugarcane vinasse using Nile tilapia (Oreochromis niloticus) as a test organism. A bioassay was performed after vinasse percolation in laboratory soil columns. The bioassay included one control group containing fresh water and two treatment groups, the first exposed to a $2,5 \%$ dilution of leached of vinasse and the second to a $2,5 \%$ dilution of in natura vinasse. After exposure, histopathological analysis was performed in gills and livers, and the latter were labelled for HSP70 proteins. No significant changes were detected in the gills of the exposed fish. However, in the liver, both in natura and leached vinasse induced statistically significant histopathological changes. These changes include hydropic degeneration, cell boundary losses, pyknotic nuclei and cellular disorganization. HSP70 expression significant increase in liver of both treatment groups were observed, being higher for the in natura vinasse exposed group. Results suggested that both leached vinasse and in natura vinasse were toxic, its still able to provoke histological changes and induce the cytoprotective response in exposed fish liver, evidenced by a immunostaining of cellular stress proteins. Thus, in order to reduce its environmental impact, appropriated effluent disposal is essential.
\end{abstract}

\section{Introduction}

In the last decade there has been a steady increase in the biofuels demand as an alternative to fossil fuels worldwide. Stimulated by the 1970s oil crisis, the searching for biofuel was intensified in order to increase energy security, offset greenhouse gas emissions and support rural economies, leading to a rapid expansion in the "green" fuels production. However, several environmental impacts related to biofuel production and agro-residues disposal have been reported in the literature, and biofuel usage continues to be a controversial subject (Van der Voet et al., 2010; Tsao et al., 2012; Lazarevic and Michael, 2016).

Sugarcane ethanol represents the main alternative to fossil fuels. Ethanol production from sugarcane biomass includes a distillation process that results in a high amount of liquid by-product residue, the vinasse or liquid stillage, obtained in a proportion of ten to fifteen times greater than the ethanol (España-Gamboa et al., 2012; Christofoletti et al., 2013). In general, it is characterized by acidic $\mathrm{pH}$, high electrical conductivity, high organic content (as organic acids), high chemical oxygen demand (COD) and high biological oxygen demand (BOD) (Moran-Salazar et al., 2016; Soto et al., 2017).

Great environmental disasters happened due to the contamination of surface water sources by in natura vinasse. Therefore, since the 1980s vinasse is often used in fertirrigation of sugarcane fields (Fontanetti and Bueno, 2017). This technique is favored by its low cost and the effluent's properties, such as high water and organic matter content, as well as potassium, calcium, nitrogen and other essential plant nutrients (Christofoletti et al., 2013; Prado et al., 2013). Several studies indicate that fertirrigation improves crop productivity, affecting chemical, physical, hydraulic and biological attributes of soil (Goldemberg et al., 2008; Laime et al., 2011; Da Silva et al., 2014).

However, when applied in large volumes, in natura vinasse can cause serious environmental impacts. By modifying the soil physical

\footnotetext{
* Correspondence to: São Paulo State University (Unesp), Department of Biology, IB, Av. 24-A, 1515, CEP: 13506-900 Rio Claro, São Paulo, Brazil.

E-mail address: fontanet@rc.unesp.br (C.S. Fontanetti).
} 
properties, vinasse may either increase soil infiltration capacity, contaminating groundwater, or diminish it, promoting increased runoff with possible contamination of surface water. In addition, the recharge mechanism of groundwater and aquifers is controlled mainly by rainfall events. Thus, upon reaching the soil containing vinasse, rainwater can infiltrate or drain superficially, contaminating the water resources (Silva et al., 2007).

Considering the different vinasse behaviors in the soil, Soto et al. (2015) performed a mathematical simulation of the water and ionic transport underground flow, hypothesizing the vinasse infiltration due to fertirrigation in sugarcane crops. Results demonstrated that vinasse solute can reach groundwater level in a short time of percolation (1-3 years) depending on its depth $(6-20 \mathrm{~m})$, and that surface water resources are also susceptible to contamination in a short period of time.

Considering this scenario, the importance of ecotoxicological studies is highlighted to predict the environmental and human health risks associated with the use of complex contaminants mixtures in agricultural soils. They also support the creation of conservation programs for affected ecosystems. Its instrumental methods of analysis allow an evaluation of the contaminating agents toxicity, where and how they affect living organisms (Magalhães and Ferrão Filho, 2008).

Among the bioindicators, the Nile tilapia (Oreochromis niloticus) is widely used as experimental model for studies on aquatic toxicology. This is due to its high growth rates and good reproduction rates in captivity, resistance to handling practices, adaptation to commercial diets and tolerance to various environmental conditions (FigueiredoFernandes et al., 2006). Several studies considered the analysis of target organs such as gills and liver appropriated to investigate histological, cellular and physiological changes in organisms exposed to various contaminants (Abdel-Moneim et al., 2012; Ahmed et al., 2013; Rodrigues et al., 2017). Gills are one of the first organs to come into direct contact with substances present in the aquatic environment and are responsible for vital functions. In addition to being the main site of gas exchange, the gills are also involved in the osmoregulation, acidbase balance and excretion of nitrogenous compounds (Machado, 2015). The liver plays a crucial role in detoxification and biotransformation processes. Due to its function, position and blood supply, it is one of the most affected organs by the water pollutants (Van der Oost et al., 2003) and has been used as a reference for the analysis of tissue damage caused by environmental toxic compounds (Ameur et al., 2012; Liebel et al., 2013; Kumar et al., 2016a, 2016b).

Environmental disturbances can also lead to changes in underlying levels of organisms organization, what motivates the use of a biomarker at molecular level to complement this study. Ubiquitous cellular stress proteins (also referred to as heat shock proteins or HSPs) are recognized as being one of the primary defense mechanisms for oxidants, toxins, metals, free radicals, viruses, and their synthesis is generally increased under these stressful conditions (Biekerns, 2000; Ponomarenko et al., 2013). Under normal conditions, constitutive HSPs act as molecular chaperones in important cellular processes such as protein metabolism, cell cycle regulation and apoptosis (Kiang and Tsokos, 1998; Hightower, 1991; Richter et al., 2010). In this group, the HSP70 family (70 kDa molecular weight) stands out because it is highly conserved and extensively studied, being used to monitor environmental pollution due to its cytoprotective role in response to proteotoxic agents (Mukhopadhyay et al., 2003).

In view of the toxic effects caused by vinasse and considering the possible environmental contamination of water resources caused by percolation/leaching of this waste on the soil, the present study investigated that whether after passage through the soil column, the vinasse maintains its toxicity? And can the soil act as a filter for this so toxic residue?

To answer the questions, the vinasse was percolated in the laboratory after construction of soil column system and the residue generated was tested in water using tilapia as a model. For that, the Oreochromis niloticus histopathology of gills and liver was evaluated, as well as the immunostaining of HSP70 cellular stress proteins in the liver, after acute exposure of this effluent in natura and with leached of vinasse.

\section{Materials and methods}

\subsection{Test organism}

Thirty individuals of the species $O$. niloticus (Perciformes, Cichlidae), popularly known as Nile tilapia, were used as test organisms. With an average size of $10 \mathrm{~cm}$ and average weight of $40 \mathrm{~g}$, the specimens were obtained from a fish farm. Before exposure, the animals were acclimated for 15 days in $250 \mathrm{~L}$ tanks with adequate filtration and aeration system. Fish were fed ration every day up to $24 \mathrm{~h}$ before the beginning of bioassays. During the bioassays animals were not fed to not increase the concentration of ammonia in aquariums.

Prior to the beginning of the experiments, the present study was analyzed and approved by the "Comitê de Ética em Pesquisa no Uso Animal da UNESP"- Rio Claro, São Paulo, Brazil (CEUA - IB - UNESP CRC), protocol no. 6301 from 29.07.2015.

\subsection{Vinasse}

In the present study in natura sugarcane vinasse provided by a power plant located in state of São Paulo was used. It was transported in thermal gallon and stored in a cold room at $4{ }^{\circ} \mathrm{C}$. The leached of vinasse was obtained after the vinasse go through a percolation system in saturated soil (Rio Claro Formation) in the Basin Studies Laboratory (LEBAC) of the Institute of Geosciences and Exact Sciences of UNESP, Rio Claro Campus described in Correia et al. (2017a) as follows: To obtain the leached from the vinasse, a percolation system was developed in the Laboratory of Basin Studies of the Institute of Geosciences and Exact Sciences. The system consists of two vinasse reservoirs with constant stirring to homogenize the solution and avoid vinasse particulates decantation. The soil was compacted at field density in PVC columns $(19 \mathrm{~cm}$ high and $6.5 \mathrm{~cm}$ in diameter) and saturated previously with deionized water. From the reservoir, the vinasse reached the soil with the aid of a modified permeameter to guarantee the vinasse application to the constant and homogeneous load. The leachad was obtained through collectors installed at the end of the column after the cap, composed of a duct, sieve plate with annular and radial grooves and nylon screen, to prevent the passage of soil particles. The leaching tests were performed in a climatized room $\left(20^{\circ} \mathrm{C} \pm 3{ }^{\circ} \mathrm{C}\right)$ and the samples were kept in a cold chamber $\left(4^{\circ} \mathrm{C}\right)$ until the beginning of the experiments.

\subsection{Physico-chemical analysis of vinasse}

Physico-chemical analysis were carried out to characterize the samples of in natura vinasse and leached of vinasse in a specialized laboratory (TASQA Analytical Services Ltd., Paulínia, São Paulo, Brazil). The following parameters were measured: $\mathrm{pH}$, BOD (Biological Oxygen Demand), COD (Chemical Oxygen Demand), calcium, iron, phosphorus, potassium, sodium, and metals (aluminum, barium, lead, cobalt, copper, chrome, strontium, magnesium, manganese, molybdenum, nickel e vanadium, selenium, silicon and zinc).

\subsection{Bioassays}

The bioassays were set up in $40 \mathrm{~L}$ aquaria. Five randomly chosen acclimated fish were placed in each aquarium. The fish were arranged in three groups: control, which received water from an artesian well; test group, which received $2.5 \%$ dilution of leached of vinasse; and comparison group, which received $2.5 \%$ dilution of in natura vinasse. The bioassays were performed in triplicates and the Nile tilapia were subjected to acute exposure $(96 \mathrm{~h})$ under constant aeration and temperature $\left(24^{\circ} \mathrm{C} \pm 2{ }^{\circ} \mathrm{C}\right)$ with a $12 \mathrm{~h}$ light $/ 12 \mathrm{~h}$ dark photoperiod. 
Monitoring was carried out three times a day to verify the temperature and $\mathrm{pH}$ of the aquariums, as well as the possible mortality and changes in fish behavior.

\subsection{Animal dissection}

After the exposure period, $O$. niloticus specimens were anaesthetized with benzocaine $(0.1 \mathrm{~g}$ of benzocaine in $1 \mathrm{ml}$ ethanol per $100 \mathrm{ml}$ deionized water) and euthanized. Their second branchial arch and liver were removed by dissection in physiological saline solution. The tissues were fixed for $24 \mathrm{~h}$ in different solutions according to the analyses: Bouin solution ( $0.9 \%$ picric acid, $9 \%$ formaldehyde, and $5 \%$ acetic acid) for histological techniques, calcium-formalin (40\% formalin, $10 \%$ $\mathrm{CaCl}_{2}$, and distilled water) for histochemical techniques, Karnovsky 0,4\% for Scanning Electron Microscopy (SEM) and buffered paraformaldehyde ( $4 \%$ paraformaldehyde in 7.4 phosphate buffer saline [PBS]) for immunohistochemistry; subsequently, the materials were transferred to sodium phosphate buffer (PBS) pH 7.40.

\subsection{Scanning Electron Microscopy (SEM)}

For SEM analysis of the gills, a sample of each individual was dehydrated in a graded series of acetone $(50 \%, 75 \%, 90 \%, 95 \%$ and $100 \%$ ), critical point dried and fixed on a metallic support. The analyses were carried out using a low vacuum Tabletop Scanning Electron Microscope Hitachi TM3000. Thirty interlamellar regions of three conserved filaments of each gill were analyzed. Analysis included counting the number of chloride cells (protocol adapted from Biagini et al., 2009), evaluating the preservation of the pavement cells' ridges and the presence of swollen cells. A score from 0 to 6 was established for the observed changes. A score of 0 indicates that no changes were observed, while 6 indicated changes in the whole organ (Marinho et al., 2014; Correia et al., 2017b).

\subsection{Histology}

Portions of gills and liver were dehydrated in a graded series of ethyl alcohol (15\%, 25\%, 50\%, 65\%, 70\%, 80\%, 90\%, 95\% and 100\%). The material was then embedded in historesin and sectioned in a microtome ( $6 \mu \mathrm{m}$ thick). The sections were hydrated in a histology bath and placed on glass slides. The slides were then stained with hematoxylin and eosin (H-E) according to Junqueira and Junqueira (1983). Two slides with ten sections were analyzed for each fish, with $n=5$ for each bioassay, performed in triplicates. A total of 60 slides and 600 histological sections were analyzed for each technique. The description and histological changes evaluation were based on Bernet et al. (1999), Marinho et al. (2014) and Correia et al. (2017b) protocols.

\subsection{Histochemistry}

In order to quantify gill mucous cells, sections were stained with Periodic Acid-Schiff (PAS). Three histological sections of each slide, with three intact gill filaments from each individual were selected for evaluation of the mucous cells of 30 interlamellar regions. Two quantification methods were used: (1) manually according to histological procedures following the protocol of Biagini et al. (2009) and (2) ImageJ Software counting tool, which is based on image contrast.

\subsection{Immunohistochemistry}

Liver samples were dehydrated in a graded series of ethyl alcohol (15\%, 30\%, 50\%, 70\%, 85\%, 90\%, 95\% e 100\%) followed by xylol + alcohol and xylol (100\%). The material was then embedded in Paraplast and sectioned with the aid of a microtome ( $6 \mu \mathrm{m}$ thick). The sections were hydrated in a histology bath and placed on glass slides.

The immunohistochemical technique was performed according to the protocol proposed by Silva-Zacarin et al. (2012) and adapted by Coelho et al. (2017). For HSP70 immunostaining the primary antibody used was the HSP70 Antibody - Monoclonal Anti-Heat Shock Protein 70 (Sigma-Aldrich) and the secondary antibody was the Anti-Mouse IgG (whole molecule) - Alkaline Phosphatase antibody (Sigma-Aldrich). The EnVision (Dako ${ }^{\mathrm{TM}}$ ) G kit | 2 System/AP Rabbit/Mouse (Permanent Red) was used to reveal markings.

The results were photographed using an Olympus BX51 photomicroscope with its image capture program. The pictures were analyzed using the ImageJ software, which provided the percentage of intensely detected immunolabelled area, considering the analyzed material's total area in each histological section. Positive marking was assigned when a red-pink color was observed, which represented deposition of chromogen at the antigen-antibody binding sites. Its intensity varied according to the amount of HSP70 family proteins present in the cells. A negative marking was assigned when this coloring was not observed.

\subsection{Statistical analysis}

To ensure appropriated statistical analysis, each data set was tested for normality using the Shapiro-Wilk method. The parametric ANOVA unidirectional test with Tuckey post-hoc with $\mathrm{p}<0.05$ or non-parametric Kruskal- Wallis with $\mathrm{p}<0.05$ was used.

\section{Results}

\subsection{Physical-chemical analysis of vinasse}

The analyses regarding metals revealed that no element in the vinasse samples was in a concentration higher than the allowed for natural water and groundwater, as defined by CETESB (Environmental Agency of the State of São Paulo) and CONAMA (National Environment Council) (Table 1). Most of the elements detected in the vinasse had their concentration reduced after percolation in soil columns, except for aluminum, which concentration was increased.

Table 1

Physicochemical and metal analysis of vinasse samples.

\begin{tabular}{llll}
\hline Parameter & In natura Vinasse & Leached of Vinasse & GVP \\
\hline pH & 4,140 & 4,700 & - \\
DBO & 5850 & 5500 & - \\
DQO & 12,533 & 11,116 & - \\
Aluminum (mg/L) & 0,580 & 1,910 & 0,005 \\
Barium (mg/L) & 0,920 & 0,037 & 0,001 \\
Calcium (mg/L) & 527,000 & 35,500 & 0,003 \\
Chromium (mg/L) & 0,014 & 0,001 & 0,003 \\
Cobalt (mg/l) & 0,012 & 0,001 & 0,003 \\
Copper (mg/L) & 0,042 & 0,004 & 0,004 \\
Iron (mg/L) & 6,920 & 0,077 & 0,005 \\
Lead (mg/L) & $<$ QL & 0,002 & 0,005 \\
Magnesium (mg/L) & 269,000 & 13,562 & 0,002 \\
Manganese (mg/L) & 2170 & 0,140 & 0,001 \\
Molybdenum (mg/L) & $<\mathrm{QL}$ & 0,003 & 0,005 \\
Nickel (mg/L) & 0,017 & 0,001 & 0,003 \\
Phosphorus (mg/L) & 11,600 & 0,071 & 0,005 \\
Potassium (mg/L) & $2,660,000$ & 132,540 & 0,030 \\
Selenium (mg/L) & 0,008 & 0,001 & 0,005 \\
Silicon (mg/L) & 18,100 & 1,151 & 0,060 \\
Sodium (mg/L) & 31,300 & 1,356 & 0,015 \\
Strontium (mg/L) & 1,550 & 0,084 & 0,005 \\
Vanadium (mg/L) & 0,032 & 0,027 & 0,003 \\
Zinc (mg/l) & 2,390 & 0,087 & 0,005 \\
\hline
\end{tabular}

QL: quantification limit, GVP: Guiding Values $(\mathrm{mg} / \mathrm{kg}$ ) of Prevention and Intervention for Soil and Groundwater according to CETESB (CETESB: Environmental Agency of São Paulo State/Brazil - 195/2005-E), Method: SMEWW: Standard Methods for the Examination of Water and Wastewater 3120B. 

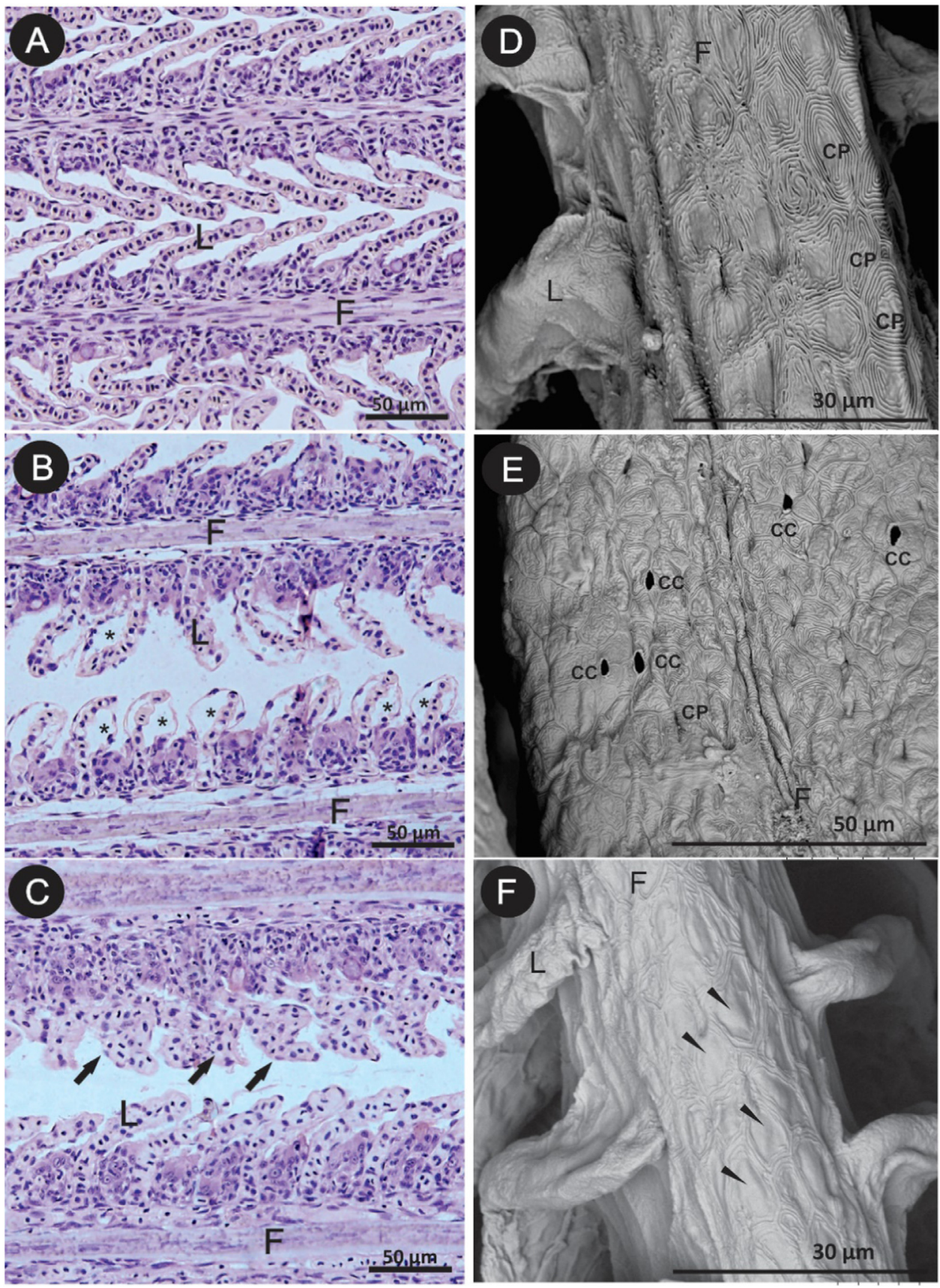

Fig. 1. Histological sections (A-C) stained by Hematoxylin-Eosin (H-E) and Scanning Electron Microscopy (D-F) from O. niloticus gills. Control (A and D); Main changes observed for the treatments (C-D and F-G). (* in B): epithelial detachment of secondary lamellae; (arrows in C): lamellar disorganization; (Arrowhead in F): swelling of the pavement cells; F: primary filament; L: secondary lamella.

\subsection{Mortality}

Five out of the thirty initial individuals died during the bioassay: one in the control group, one in the group exposed to in natura vinasse and three in the group exposed to leached of vinasse.

\subsection{Gill analyses}

\subsubsection{Scanning Electron Microscopy}

Chloride cells quantification (Fig. 1A) revealed similar results (Table 2) between treatments. No significant differences were observed between groups. Pavement cells (Fig. 1B) of both treatment groups preserved ridges, similar to those in the control group. Again, no significant differences were observed between groups. However, a
Table 2

Quantification of chloride and mucous cells on $O$. niloticus gills exposed to leached of vinasse.

\begin{tabular}{llll}
\hline & Chloride cells & Mucous cells \\
\cline { 3 - 4 } Treatment & Biagini Protocol & Biagini Protocol & Image J \\
\hline Control & $34,000 \pm 31,524$ & $256,222 \pm 35,760$ & $0,811 \pm 0,307$ \\
In natura Vinasse & $30,000 \pm 18,444$ & $211,800 \pm 37,500$ & $0,510 \pm 0,137$ \\
Leached of vinasse & $32,500 \pm 32,943$ & $236,375 \pm 76,280$ & $0,884 \pm 0,422$
\end{tabular}

There are no statistically significant values by the Kruskal-Wallis test with $\mathrm{p}<0.05$ compared to the negative control. Values presented as mean \pm SD. 
Table 3

Main alterations observed in $O$. niloticus gills and livers exposed to vinasse, and their corresponding factor of importance.

\begin{tabular}{lll}
\hline Organ & Characteristics examined & Factor of Importance (w) \\
\hline \multirow{2}{*}{ Gills } & Epithelial detachment & 1 \\
& Lamellar disorganization & 1 \\
& Hemorrhage & 1 \\
& Edema & 1 \\
& Epithelial invasion & 1 \\
& Hyperplasia & 2 \\
& Hypertrophy & 1 \\
Hepatocytes & Pavement cell swelling & 1 \\
& Hydropic degeneration & 2 \\
& Loss of cell boundary & 3 \\
& Pyknotic nucleus & 3 \\
& Increased nucleus size & 2 \\
& Vacuolated cytoplasm & 1 \\
Hepatic Tissue & Loss of cytoplasmic integrity & 3 \\
& Disorganization of tissue & 2 \\
\hline
\end{tabular}

swelling of the pavement cells was observed (Fig. 1C). Its alteration index was statistically significant for the group exposed to leached of vinasse in comparison to the control. The index was of 1.5 on a 1-6 scale, which is considered a very low index.

\subsubsection{Histological analyses}

Gills analyses in the control group (Fig. 1D) showed the standard morphological structure described for teleosts (Machado, 2015). The most frequently observed histological changes were epithelial detachment (Fig. 1E) and lamellar disorganization (Fig. 1F). In addition, hemorrhage, edema, and epithelial invasion were also observed. The importance factors for each alteration found in the gills are presented in Table 2. However, all alterations presented low indexes; therefore, there were no statistically significant differences in the treatments in comparison to the control (Table 4).

\subsubsection{Histochemistry}

Mucous cell analysis according to the protocol established by Biagini et al. (2009) (Table 3) did not reveal statistically significant differences for the treatments in comparison to the control. ImageJ Software (Table 3) was used to calculate the percentage of mucous cells per area. This analysis also did not reveal statistically significant differences between groups. Cells from both treatments showed no reduction in size and/or abnormal morphology.

\subsection{Liver analyses}

\subsubsection{Histological analyses}

Liver analyses indicate standard liver tissue morphology as described by Akiyoshi and Inoue (2004) in the control group. The standard tissue morphology consists of hepatocytes with well-defined nuclei, homogeneous or occasionally less stained cytoplasm, interspersed by sinusoids where the erythrocytes are observed (Fig. 2A, B). Pancreatic tissue distributed along the hepatic parenchyma is also observed.

However, the groups exposed to in natura vinasse and leached of vinasse showed several histopathological changes (Tables 3 and 4). Statistically significant changes in both treatments, when compared to the control group, were: loss of cell boundary (Fig. 2E), presence of pyknotic nucleus (Fig. 2D), loss of cytoplasmic integrity and disorganization of hepatic tissue (Fig. 2D). The group exposed to leached of vinasse also showed higher presence of cytoplasmic vacuoles (Fig. 2C), which was statistically significant in comparison to the control and to the group exposed to in natura vinasse. Hydropic degeneration (Fig. 2E) and increased nucleus size (Fig. 2F, G) observed in the group exposed to in natura vinasse were also statistically significant in comparison to the control group.

\subsubsection{Immunohistochemical analyses}

HSP70 cellular stress protein immunostaining in $O$. niloticus liver samples were significantly elevated in comparison to the control group for both in natura vinasse and leached of vinasse treatments. Detection occurred predominantly in the periphery of the analyzed livers (Fig. 3).

\section{Discussion}

The high amount of vinasse released in the field as fertilizer generates a great cost-benefit for the sugar and alcohol industry since it generates savings on artificial fertilizers and at the same time reuses the vinasse produced. However, this practice raises concerns for environmentalists regarding its environmental impact, since this residue has a high organic load and is proven to be toxic (Marinho et al., 2014; Correia et al., 2017b; 2017c) can reach water resources by leaching in a few years (Soto et al., 2015).

Comparisons between the metals analysis of in natura and leached of vinasse suggest that the soil is an efficient filter for metal immobilization. The elements found presented lower concentrations, except for aluminum (Al), which concentration increased. The increase of $\mathrm{Al}$ concentration may be due the high concentration in which it is found in the latosol-type clay soil of the region where the soil was collected. This soil is rich in iron and aluminum oxides and hydroxides, displaying reddish/yellowish colors, typical of the soil of tropical countries (Toledo et al., 2000).

Aluminum is one of the most abundant elements on earth (Fernández-Dávila et al., 2012). Its most toxic form for fish is inorganic (Al); as the $\mathrm{pH}$ of the medium is acidified, the aluminum available there polymerizes. This process leads to an increase in its toxicity due to the decrease of its solubility that favors the accumulation of this metal in the organisms (Poléo, 1995). In addition, aluminum interferes with ionic and osmotic regulation (Andrén and Rydin, 2012). Thus, the Al may have been entrained during the percolation process and accumulated in the resulting solution.

Although the soil is a natural protection barrier to underground aquifers, its metal retainment attributes are extremely complex. Therefore, it is difficult to predict its behavior, especially long-term. It is known that the mobility of metals will be determined by soil attributes (Oliveira et al., 2001). The high content present in the vinasse when adsorbed in the soil matrix may promote the following changes in soil: $\mathrm{pH}$ increase, decreased oxidation potential, increased cation exchange capacity (Soto et al., 2017).

As for the gills analyses, it is known that pavement cells are the most common cell type in the branchial epithelium. Its ridges are ancillary to mucus retention, which contributes to protect lamellar surfaces against environmental changes, such as toxic or infectious agents and suspended particles (Mallat, 1985). Electron microscopy did not reveal damage to the gills exposed to the percolated of vinasse, nor to the in natura vinasse, since the pavement cells ridges were similar to the control. The swelling of the pavement cells observed in the group exposed to leached of vinasse was significant, but the assigned score was low.

The number of chloride cells was not altered in comparison to the control for both treatments. The chloride cells are large and usually scattered on the lamellae surface. These are rich in mitochondria and participate in the ions active transport, and can show altered shape, structure, morphology and number due to changes in environmental factors (Pereira and Caetano, 2009). Chloride cells quantification revealed no statistically significant differences for the treatments in comparison to the control. It suggests that the leached of vinasse did not cause differences in the number of these cells.

Histological analyses revealed low alterations scores for both in natura and leached of vinasse. Neither presented statistically significant differences in comparison to the control. The main alterations were 

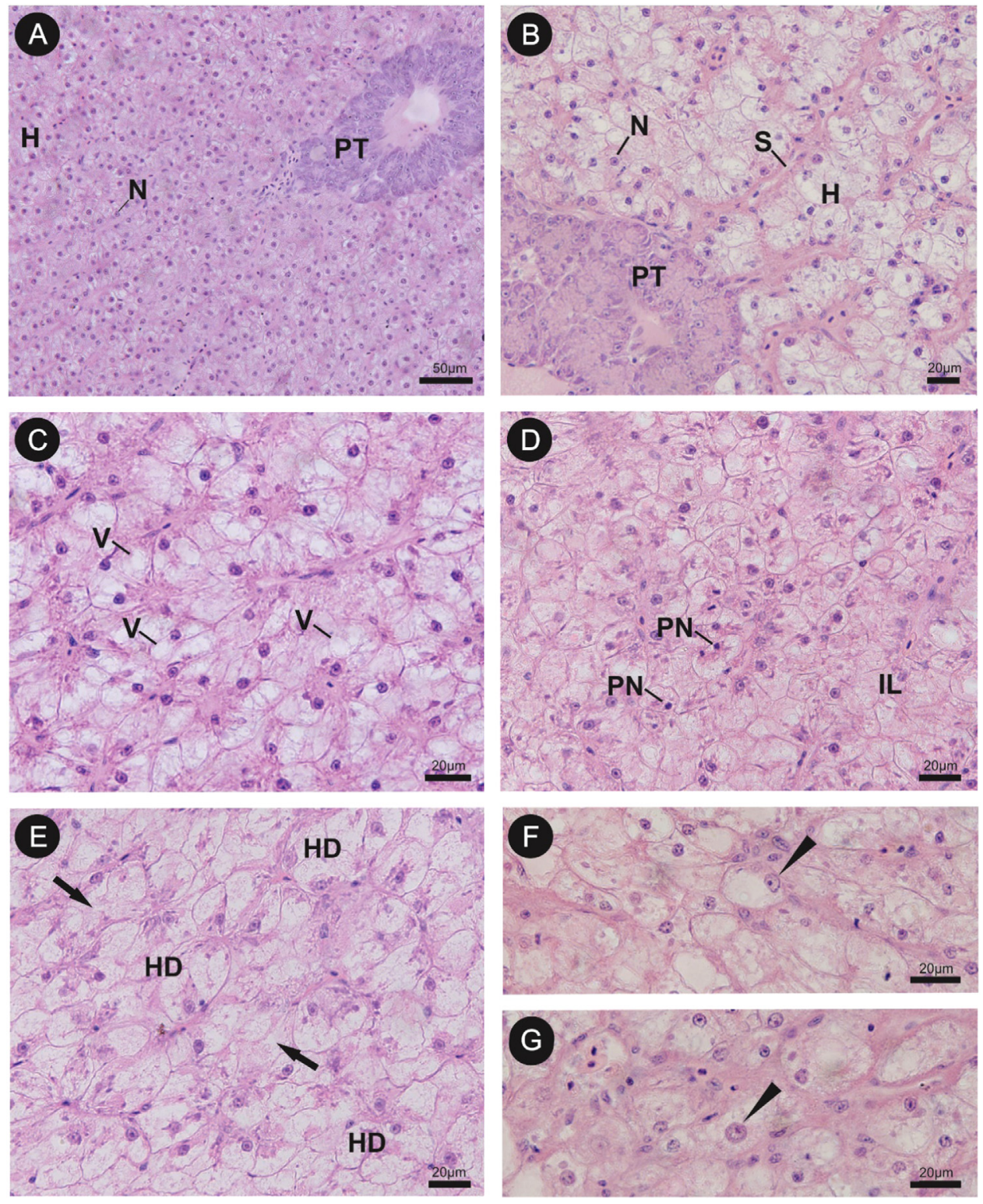

Fig. 2. Histological sections stained by Hematoxylin and Eosin (H-E) from O. niloticus livers exposed to leached of vinasse. Control (A and B); Main changes observed for the treatments (C-G). H: Hepatocyte; N: Nucleus; PT: Pancreatic tissue; S: Sinusoid; V: Cytoplasmic vacuoles; PN: Pyknotic nucleus; IL: Loss of cytoplasmic integrity; HD: Hydropic Degeneration; Arrow: loss of cytoplasmic boundary; Arrowhead: Increase in nucleus size.

epithelial detachment and lamellar disorganization, with a mean index of 0.4 on a scale of $0-6$. Epithelial detachment functionally reduces the organ to diminish contamination by the toxic substance (Bernet et al., 1999). Both alterations have minimal pathological importance, meaning that the lesion is reversible when exposure to the stressor ceases.

Mucous cells produce mucus that performs the protective function of the gill tissue. The increase in this cell type may indicate the presence of toxic substances in the water (David and Fontanetti, 2009). However, the mucous cells quantification by both the protocols of Biagini et al. (2009) and by the percentage analysis of ImageJ software, did not reveal statistically significant differences when compared to the control.

However, Correia et al. (2017b) have demonstrated the dilutions of in natura vinasse toxic effects in gills of $O$. niloticus. The effluent caused histopathological alterations such as loss of pavement cell ridges, swelling, epithelial detachment and lamellar disorganization that were statistically significant in relation to the control. There was also a significant increase in the number of mucous cells and chloride cells.

Unlike the response in the gills, vinasse caused significant changes in the livers. Alterations such as loss of cell boundary, pyknotic nucleus, loss of cytoplasmic integrity and disorganization of hepatic parenchyma were statistically significant in the groups exposed to both in natura and leached of vinasse. The hydropic degeneration and increase of nuclei were also significant in the group exposed to in natura vinasse. An increase of cytoplasmic vacuoles in the group exposed to the leached of vinasse was also significant. This can be explained by the fact that the liver of teleosts is one of the most sensitive organs. Exposure to different types of environmental pollutants may alter its morphology, biochemistry and physiology (Ahmed et al., 2013; Alesci et al., 2014).

Similar to other pollutants such as pesticides (Fanta et al., 2003; Pesce et al., 2008; Ansoar-Rodríguez et al., 2016), exposure to vinasse caused morphological alterations in hepatocytes, which became irregular and lost their cell boundaries. These changes provoke loss of the hepatic parenchyma architecture (tissue disorganization) that can lead to serious physiological consequences (Barja-Fernández et al., 2013).

The presence of hepatocytes with reduced-diameter, densely-heterochromatic and pyknotic-like nuclei was found to be significant in this study and in studies evaluating the vinasse effects (Marinho et al., 
Table 4

Frequency of occurrence of significant alterations in gills and liver found in $O$. niloticus exposed to vinasse.

\begin{tabular}{|c|c|c|c|c|}
\hline Organ & Alteration & Control & In natura Vinasse & Leached of vinasse \\
\hline \multirow[t]{8}{*}{ Gills } & Epithelial detachment & $0,410 \pm 0,770$ & $0,320 \pm 0,540$ & $0,430 \pm 0,620$ \\
\hline & Epithelial disorganization & $0,440 \pm 0,520$ & $0,970 \pm 0,750$ & $0,430 \pm 0,390$ \\
\hline & Hemorrhage & $0,130 \pm 0,180$ & $0,270 \pm 0,360$ & $0,150 \pm 0,350$ \\
\hline & Edema & 0 & $0,120 \pm 0,170$ & 0 \\
\hline & Epithelial invasion & $0,190 \pm 0,270$ & $0,250 \pm 0,350$ & $0,060 \pm 0,170$ \\
\hline & Hyperplasia & $0,160 \pm 0,350$ & 0 & 0 \\
\hline & Hypertrophy & $0,500 \pm 0,900$ & $1,900 \pm 1,660$ & $0,300 \pm 0,530$ \\
\hline & Pavement cell swelling & $1,000 \pm 0$ & $1,000 \pm 0,220$ & $1,500 \pm 0,530^{*}$ \\
\hline \multirow[t]{8}{*}{ Liver } & Loss of pavement cell ridges & $3,500 \pm 1,200$ & $3,500 \pm 0,790$ & $3,500 \pm 0,910$ \\
\hline & Hydropic degeneration & $3,030 \pm 1,250$ & $6,800 \pm 1,190^{*}$ & $5,000 \pm 0,910$ \\
\hline & Loss of cell boundary & $0,35 \pm 0,99$ & $11,360 \pm 2,020^{*}$ & $12,970 \pm 1,470^{*}$ \\
\hline & Pyknotic nucleus & $0 \pm 0$ & $4,450 \pm 2,320^{*}$ & $4,930 \pm 2,480^{*}$ \\
\hline & Increased nucleus size & $0,040 \pm 0,140$ & $1,730 \pm 1,100^{*}$ & $0,400 \pm 0,880$ \\
\hline & Vacuolated cytoplasm & $2,310 \pm 0,840$ & $0,850 \pm 0,750$ & $4,800 \pm 0,730^{*}$ \\
\hline & Loss of cytoplasmic integrity & $2,510 \pm 2,090$ & $10,310 \pm 2,810^{*}$ & $11,260 \pm 1,640^{*}$ \\
\hline & Disorganization of hepatic tissue & $0,370 \pm 0,700$ & $6,790 \pm 2,020^{*}$ & $6,860 \pm 1,010^{*}$ \\
\hline
\end{tabular}

Values presented as mean \pm SD.

* Statistically significant when compared to the control by one-way ANOVA/Tukey, $\mathrm{p}<0.05$.

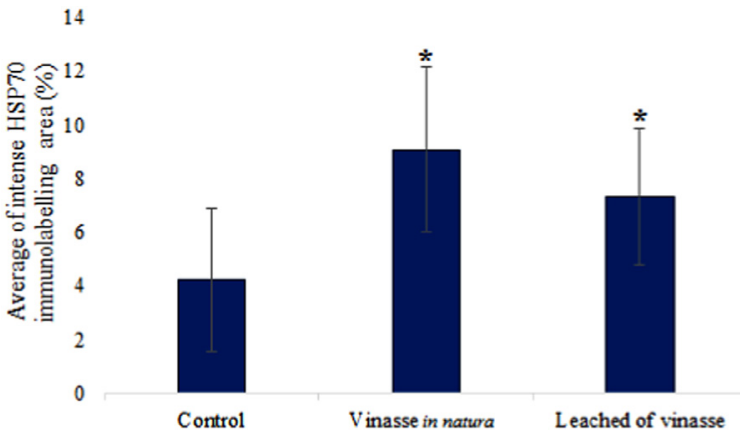

Fig. 3. Average of intense HSP70 immunolabelling area in O. niloticus liver obtained using the ImageJ program (means $\pm \mathrm{SD}$ ). Values expressed as percentage. * Statistically significant when compared to the other groups by oneway ANOVA/Tukey, $\mathrm{p}<0.05$.

2014), glyphosate herbicides (Jiraungkoorskul et al., 2003), diquat (Henares et al., 2008) and the imidacloprid pesticide (AnsoarRodríguez et al., 2016) in livers of Nile tilapia. This study found that the cells became hypofunctional in a possible cell death process in response to the vinasse toxic potential (Fanta et al., 2003; Marinho et al., 2014).

Due to its detoxification role, the liver is exposed to a higher concentration of toxic agents when compared to other organs, what may cause pollutants to accumulate in this organ (Barja-Fernández et al., 2013). Thus, an increase in detoxification activity may lead to cellular and nuclear hypertrophy (hydropic degeneration and nucleus size increase, respectively) in hepatocytes. This response was observed here and was significant for the group exposed to in natura vinasse. In this sense, it can be deduced that in natura vinasse has been shown to be relatively more toxic than its leached form.

Regarding the leaching of vinasse in particular, a higher number of cytoplasmic vacuoles was observed. This may be indicative of an imbalance between the rate of synthesis of substances in the parenchymal cells and the rate of their release into the systemic circulation (Jiraungkoorskul et al., 2003). In fact, although lipid accumulation may be part of a normal physiological process, its significant increase may indicate a mechanism for defense against lipid-soluble contaminants (Biagianti-Risbourg et al., 1997), such as metals present in vinasse.

It is known that the metal constituents of vinasse can modify the activity of liver enzymes and lead to histopathological changes in the liver (Paris-Palacio et al., 2000), as it is the metabolic center of the body's detoxification process. In this sense, it is important to consider that the hepatic changes observed in the present study can have secondary effects in the whole organism. However, it is not possible to establish a direct relationship between metal constituents and the damages observed because the vinasse is a complex mixture. Its toxicity can also result from additive or synergistic effects of the substances (Alves et al., 2015).

Complementing this histopathological analysis, a biomarker at the molecular level was used. In fact, the first response to any environmental stress condition occurs at the subcellular level through the selective overexpression of highly conserved proteins called heat shock proteins (HSPs) (Bakthisaran et al., 2015). Among them, the most studied are HSP70, molecular chaperones that help in the refolding and membrane translocation of damaged proteins. It prevents the formation of cytotoxic aggregates and the apoptotic process (Fink, 1999; Castro et al., 2013). Thus, through their cytoprotective action, these proteins act in the restoration of cellular homeostasis.

In relation to fish liver in particular, Schröder et al. (2000) validated hepatic HSP70 as an efficient biomarker for the monitoring of environmental pollution. These authors correlated the high levels of protein to the damage found in the fish species Limanda limanda DNA. Several studies also support the significant increase in the expression of HSP70 in fish liver as a way to evaluate the response to environmental contaminants such as pesticides, sewage treatment effluents, metals, through direct exposure or through the food chain. Other studies have shown that there is a high correlation between the number of species and the number of species that can be found in this region (Varo et al., 2002; Ceyhun et al., 2010; Rajeshkumar, Munuswamy, 2011; Cuklev et al., 2012; Rajeshkumar et al., 2013; Ansoar-Rodríguez et al., 2016).

The high aluminum concentrations found in natural vinasse and especially in the leached of vinasse may be a major factor in its toxicity. Teinen et al. (2008) reported that aluminum was able to accumulate in Pansky Pond fish, damaging the gill epithelium of these animals. In the present study, the presence of gills, kidneys and liver of fish of the species Catla catla, Labeo rohita and Cirrhina mrigala (Azmat et al., 2012).

The present study observed a significant immunolabelling increase of this family of proteins in the liver of animals exposed to vinasse in both in natura and leached forms when compared to the control group. This may be due to the proteotoxic action of this residue. Its adverse effects on the integrity of the intracellular proteins would have activated the biochemical signaling cascade, culminating in the transcription of heat shock genes and the accumulation of these molecular chaperones detected by immunohistochemistry (Pirkkala et al., 2001). Thus, HSP70 would be acting in cell repair and detoxification machinery (Bierkens, 2000), presumably in response to oxidative stress induced by exposure to the residue, what correlates with the histopathological changes observed in the organ. 


\section{Conclusion}

Based on the results obtained through analyses of the metals in the vinasses, it can be concluded that the soil working as a filtering medium during vinasse percolation through the soil. It reduces the vinasse constituent metals concentration, attenuating the organic/inorganic load of the solution that will reach the water after infiltration.

Histopathological analyses have shown that in natura and leached of vinasse presented toxicity and it was capable of promoting significant alterations, which were comparatively more severe in the liver. In addition, vinasse was shown to induce proteotoxic action triggering cytoprotective responses such as increased expression of the HSP70 family of stress proteins. As a result, there was greater immunostaining of these proteins in the response to in natura vinasse in relation to the leached form.

Accordingly, the vinasse use as a fertilizer requires caution. Its toxic potential, for both in natura and leached forms, should receive greater attention in order to reduce its environmental impact. In addition, it is worth emphasizing the soil salinization risk with the continuous use of vinasse, due to the biochemical characteristics of this residue.

\section{Acknowledgments}

The authors are thankful to Fundação de Amparo à Pesquisa de São Paulo - FAPESP, Brazil (Process no. 2012/50297-2, 2015/156245 and 2015/15623-9) and Coordenação de Aperfeiçoamento de Pessoal de Nível Superior - CNPq, Brazil, for the financial support, and to Gerson Mello de Souza for the technical support.

\section{Conflict of interest}

The authors declare that they have no conflict of interest.

\section{References}

Abdel-Moneim, A.M., Al-Kahtani, M.A., Elmenshawy, O.M., 2012. Histopathological biomarkers in gills and liver of Oreochromis niloticus from polluted wetland environments. Saudi Arab. Chem. 88, 1028-1035.

Ahmed, M.K., Habibullah-Al-Mamun, M., Parvin, E., Akter, M.S., Khan, M.S., 2013. Arsenic induced toxicity and histopathological changes in gill and liver tissue of freshwater fish, tilapia (Oreochromis mossambicus). Exp. Toxicol. Pathol. 65 (6), 903-909.

Akiyoshi, H., Inoue, A., 2004. Comparative histological study of teleost livers in relation to phylogeny. Zool. Sci. 21 (8), 841-850.

Alesci, A., Cicero, N., Salvo, A., Palombieri, D., Zaccone, D., Dugo, G., Bruno, M., Vadalà, R., Lauriano, E.R., Pergolizzi, S., 2014. Extracts deriving from olive mill waste water and their effects on the liverof the goldfish Carassius auratus fed with hypercholesterolemic diet. Nat. Product. Res. 28, 1343-1349.

Alves, P.R.L., Natal-da-Luz, T., Sousa, J.P., Cardoso, E.J., 2015. Ecotoxicological characterization of sugarcane vinasses when applied to tropical soils. Sci. Total Environ. 526, 222-232.

Ameur, W.B., de Lapuente, J., El Megdiche, Y., Barhoumi, B., Trabelsi, S., Camps, L., Serret, J., Ramos-López, D., Gonzalez-Linares, J., Driss, M.R., Borràs, M., 2012. Oxidative stress, genotoxicity and histopathology biomarker responses in mullet (Mugil cephalus) and sea bass (Dicentrarchus labrax) liver from Bizerte lagoon (Tunisia). Mar. Pollut. Bull. 64 (2), 241-251.

Andrén, C.M., Rydin, E., 2012. Toxicity of inorganic aluminium at spring snowmelt-Instream bioassays with brown trout (Salmo trutta L.). Sci Total Environ 437, 422-432.

Ansoar-Rodríguez, Y., Christofoletti, C.A., Correia, J.E., Souza, R.B., Moreira-de-Sousa, C., Marcato, Bueno, O.C., Malaspina, O., Silva-Zacarin, E.C.M., Fontanetti, C.S., 2016. Liver alterations in Oreochromis niloticus (Pisces) induced by insecticide imidacloprid: Histopathology and heat shock protein in situ localization. J. Environ. Sci. Health Part B 51 (12), 881-887.

Azmat, H., Javed, M., Jabeen, G., 2012. Acute toxicity of aluminium to the fish (Catla catla, Labeo rohita and Cirrhina mrigala). Pak. Vet. J. 32 (1), 85-87.

Bakthisaran, R., Tangirala, R., Rao, M., 2015. Small heat shock proteins: role in cellular functions and pathology. J. Biochem. Biophys. Acta 1854, 291-319.

Barja-Fernández, S., Míguez, J.M., Álvarez-Otero, R., 2013. Histopathological effects of 2, $2^{\prime}, 4,4^{\prime}$-tetrabromodiphenyl ether (BDE-47) in the gills, intestine and liver of turbot (Psetta maxima). Ecotoxicol. Environ. Saf. 95, 60-68.

Bernet, D., Schmidt, H., Meier, W., Burkhardt-Holm, P., Wahli, T., 1999. Histopathology in fish: proposal for a protocol to assess aquatic pollution. J. Fish Dis. 22, 25-34.

Biagianti-Risbourg, S., Pairault, C., Vernet, G., Boulekbache, H., 1997. Effect of lindane on the ultrastructure of the the liver of the rainbow trout, Oncorhynchus mykiss. Sac-Fry Chem. 33, 2065-2079.
Biagini, F.R., David, J.A.O., Fontanetti, C.S., 2009. The use of histological, histochemical and ultramorphological techniques to detect gill alterations in Oreochromis niloticus reared in treated polluted waters. Micron 40, 839-844.

Bierkens, J.G.E.A., 2000. Applications and pitfalls of stress proteins in biomonitoring. Toxicol 153, 61-72.

Castro, S.V., Lobo, C.H., Figueiredo, J.R., Rodrigues, A.P.R., 2013. Proteínas de choque termico hsp 70: Estrutura e atuação em resposta ao estresse celular. Acta Vet. Bras. 7 (4), 261-271.

Ceyhun, S.B., Senturk, M., Ekinci, D., Erdogan, O., Ciltas, A., Kocaman, E.M., 2010. Deltamethrin attenuates antioxidante defende system and induces the expression of heat shock protein 70 in rainbow trout. Comp. Biochem. Physiol. C Toxicol. Pharmacol. 152, 215-223.

Christofoletti, C.A., Pedro Escher, J., Correia, J.E., Urbano Marinho, J.F., Fontanetti, C.S. 2013. Sugarcane Vinasse: environmental Implications of Its Use. Waste Manag. 33, 2752-2761.

Coelho, M.P.M., Moreira-de-Sousa, C., de Souza, R.B., Ansoar-Rodríguez, Y., SilvaZacarin, E.C.M., Fontanetti, C.S., 2017. Toxicity evaluation of vinasse and biosolid samples in diplopod midgut: heat shock protein in situ localization. Environ. Sci. Pollut. Res. 24 (27), 22007-22017.

Correia, J.E., Marcato, A.C.C., Christofoletti, C.A., Soto, M. A., Fontanetti, C.S., 2017a Toxicidade e genotoxicidade da vinhaça de cana-de-açúcar em peixes em bioensaios laboratoriais. In: Fontanetti, C.S., Bueno, O.C. (Org.). Cana-de-açúcar e seus impactos: uma visão acadêmica. Bauru - SP: Canal 6. pp. 31-50.

Correia, J.E., Christofoletti, C.A., Marcato, A.C.C., Marinho, J.F.U., Fontanetti, C.S., 2017a. Histopathological analysis of tilapia gills (Oreochromis niloticus Linnaeus, 1758) exposed to sugarcane vinasse. Ecotoxicol. Environ. Saf. 135, 319-326.

Correia, J.E., Christofoletti, C.A., Ansoar-Rodríguez, Y., Guedes, T.A., Fontanetti, C.S., 2017b. Comet assay and micronucleus tests on Oreochromis niloticus (Perciforme: Cichlidae) exposed to raw sugarcane vinasse and to phisicochemical treated vinasse by pH adjustment with lime (CaO). Chem 173, 494-501.

Cuklev, F., Gunnarsson, L., Cvijovic, M., Kristiansson, E., Rutgersson, C., Björlenius, B., Larsson, D.J., 2012. Global hepatic gene expression in rainbow trout exposed to sewage effluents: a comparison of different sewage treatment technologies. Sci. Total Environ. 427, 106-114.

Da Silva, A.P.M., Bono, J.A., Pereira, F.D.A., 2014. Aplicação de vinhaça na cultura da cana-de-açúcar: Efeito no solo e na produtividade de colmos. Rev. Bras. Eng. Agríc. Ambient. 18 (1), 38-43.

David, J.A.O., Fontanetti, C.S., 2009. The role of mucus in Mytella falcata (Orbigny, 1842) gills from polluted environments. Water Air Soil Pollut. 203, 261-266.

España-Gamboa, E.I., Mijangos-Cortés, J.O., Hernández-Zárate, G., Maldonado, J.A.D., Alzate-Gaviria, L.M., 2012. Methane production by treating vinasses from hydrous ethanol using a modified UASB reactor. Biotechnol. Biofuels 5 (1), 82.

Fanta, E., Rios, F.S., Romão, S., Vianna, A.C., Freiberger, S., 2003. Histopathology of the fish Corydoras paleatus contaminated with sublethal levels of organophosphorus in water and food. Ecotoxicol. Environ. Saf. 54, 119-130.

Fernández-Dávila, M.L., Razo-Estrada, A.C., García-Medina, S., Gómez-Oliván, L.M., Piñón-López, M.J., Ibarra, R.G., Galar-Martínez, M., 2012. Aluminum-induced oxidative stress and neurotoxicity in grass carp (Cyprinidae-Ctenopharingodon idella). Ecotox Environ Safe 76, 87-92.

Figueiredo-Fernandes, A., Fontaínhas-Fernandes, A., Monteiro, R., Reis Henriques, M.A., Rocha, E., 2006. Effects of the fungicide mancozeb on liver structure of nile tilapia, Oreochromis niloticus: assessment and quantification of induced cytological changes using qualitative histopathology and the stereological point-sampled intercept method. Bull. Environ. Contam. Toxicol. 76, 249-255.

Fink, A.I., 1999. Chaperone-mediated protein folding. Physiol. Ver. 79, 425-449.

Fontanetti, C.S., Bueno, O.C. (Org.), 2017. Cana-de-açúcar e seus impactos: uma visão acadêmica. Bauru, SP: Canal 6. p. 275.

Goldemberg, J., Coelho, S.T., Guardabassi, P., 2008. The sustainability of ethanol production from sugarcane. Energy Policy 36 (6), 2086-2097.

Henares, M.N.P., Cruz, C., Gomes, G.R., Pitelli, R.A., Machado, M.R.F., 2008. Toxicidade aguda e efeitos histopatológicos do herbicida diquat na brânquia e no fígado da tilápia nilótica (Oreochromis niloticus). Acta Sci. Biol. Sci. 30 (1), 77-82.

Hightower, L.E., 1991. Heat shock, stress proteins, chaperones, and proteotoxicity. Cell 66 (2), 191-197.

Jiraungkoorskul, W., Upatham, E.S., Kruatrachue, M., Sahaphong, S., Vichasri-Grams, S., Pokethitiyook, P., 2003. Biochemical and histopathological effects of glyphosate herbicide on Nile tilapia (Oreochromis niloticus). Env. Toxicol. 18 (4), 260-267.

Junqueira, L.C.U., Junqueira, L.M.S., 1983. Técnicas Básicas de Citologia e Histologia; Junqueira, G.J.P. (Eds.). Santos Editora: São Paulo, Brazil, 102p.

Kiang, J.G., Tsokos, G.C., 1998. Heat shock protein 70 kDa: molecular biology, biochemistry, and physiology. Pharmacol. Ther. 80 (2), 183-201.

Kumar, N., Krishnani, K.K., Gupta, S.K., Singh, N.P., 2016a. Cellular stress and histopathological tools used as biomarkers in Oreochromis mossambicus for assessing metal contamination. Environ. Toxicol. Pharmacol. 49, 137-147.

Kumar, N., Sharma, R., Tripathi, G., Kumar, K., Dalvi, R.S., Krishna, G., 2016b. Cellular metabolic, stress, and histological response on exposure to acute toxicity of endosulfan in Tilapia (Oreochromis mossambicus). Environ. Toxicol. 31 (1), 106-115.

Laime, E.M.O., Fernandes, P.D., Oliveira, D., Freire, E.A., 2011. Possibilidades tecnológicas para a destinação da vinhaça: uma revisão. Rev. Trop. Ci. Agr. Biol. 5 (16), 16-29.

Lazarevic, D., Michael, M., 2016. Life cycle assessments, carbon footprints and carbon visions: analysing environmental systems analyses of transportation biofuels in Sweden. J. Clean. Prod. 137, 249-257.

Liebel, S., Tomotake, M.E.M., Ribeiro, C.A.O., 2013. Fish histopathology as biomarker to evaluate water quality. Ecotoxicol. Environ. Cont. 8 (2), 09-15.

Machado, M.R., 2015. Uso de brânquias de peixes como indicadores de qualidade das 
águas. J. Health Sci. 1 (1), 63-76.

Magalhães, D.P., Ferrão Filho, A.S.A., 2008. Ecotoxicologia como ferramenta no Biomonitoramento de Ecossistemas Aquáticos. Oecol. Bras. 12 (3), 355-381.

Mallat, J., 1985. Fish gill structural changes induced by toxicants and other irritants: a statistical review. Can. J. Fish. Aquat. Sci. 42, 630-648.

Marinho, J.F.U., Correia, J.E., Marcato, A.C.C., Pedro-Escher, J. Fontanetti, C.S., 2014 Sugar cane vinasse in water resources: impact assessed by liver histopathology in tilapia. Ecotoxicol. Environ. Saf. 110, 239-245.

Moran-Salazar, R.G., Sanchez-Lizarraga, A.L., Rodriguez-Campos, J., Davila-Vazquez, G., Marino-Marmolejo, E.N., Dendooven, L., Contreras-Ramos, S.M., 2016. Utilization of vinasses as soil amendment: consequences and perspectives. SpringerPlus 5 (1), 1-11.

Mukhopadhyay, I., Nazir, A., Saxena, D.K., Chowdhuri, D.K., 2003. Heat shock response: hsp70 in environmental monitoring. J. Biochem. Mol. Toxicol. 17 (5), 249-254.

Oliveira, F.C., Mattiazzo, M.E., Marciano, C.R., Moraes, S.O., 2001. Percolação de nitrato em Latossolo Amarelo Distrófico afetada pela aplicação de composto de lixo urbano e adubação mineral. R. Bras. Ci. Solo 25 (3), 731-741.

Paris-Palacio, S., Biagianti-Risbourg, S., Vernet, G., 2000. Biochemical and (ultra) structural hepatic perturbations of Brachydanio rerio (Teleostei, Cyprinidae) exposed to two sublethal concentrations of copper sulfate. Aquat. Toxicol. 50, 109-124.

Pereira, B.F., Caetano, F.H., 2009. Histochemical technique for the detection of chloride cells in fish. Micron 40 (8), 783-786.

Pesce, S.F., Cazenave, J., Monferrán, M.V., Frede, S., Wunderlin, D.A., 2008. Integrated survey on toxic effects of lindane on neotropical fish: Corydoras paleatus and Jenynsia multidentata. Environ. Pollut. 156, 775-783.

Pirkkala, L., Nykänen, P., Sistonen, L., 2001. Roles of the heat shock transcription factors in regulation of the heat shock response and beyond. FASEB J. 15, 1118-1131.

Poléo, A.B., 1995. Aluminium polymerization-a mechanism of acute toxicity of aqueous aluminium to fish. Aquatic toxicology 31 (4), 347-356.

Ponomarenko, M., Stepanenko, I., Kolchanov, N., 2013. Heat shock proteins, In: Brenner's Encyclopedia of Genetics, pp. 402- 405.

Prado, R.D.M., Caione, G., Campos, C.N.S., 2013. Filter cake and vinasse as fertilizers contributing to conservation agriculture. Appl. Environ. Soil Sci. 2013.

Rajeshkumar, S., Munuswamy, N., 2011. Impact of metals on histopathology and expression of HSP 70 in different tissues of Milk fish (Chanos chanos) of Kaattuppalli Island, South East Coast, India. Chemosphere 83 (4), 415-421.

Rajeshkumar, S., Mini, J., Munuswamy, N., 2013. Effects of heavy metals on antioxidants and expression of HSP70 in different tissues of Milk fish (Chanos chanos) of Kaattuppalli Island, Chennai, India. Ecotoxicol. Environ. Saf. 98, 8-18.
Richter, K., Haslbeck, M., Buchner, J., 2010. The heat shock response: life on the verge of death. Mol. Cell 40 (2), 253-266.

Rodrigues, S., Antunes, S.C., Nunes, B., Correia, A.T., 2017. Histological alterations in gills and liver of rainbow trout (Oncorhynchus mykiss) after exposure to the antibiotic oxytetracycline. Environ. Toxicol. Pharmacol. 53, 164-176.

Schröder, H.C., Batel, R., Hassanein, H.M.A., Lauenroth, S., Simat, T., Steinhart, H., Müller, W.E.G., 2000. Correlation between the level of the potential biomarker, heatshock protein, and the occurrence of DNA damage in the dab, Limanda limanda: a field study in the North Sea and the English Channel. Mar. Environ. Res 49 (3), 201-215.

Silva, M.A.S., Griebeler, N.P., Borges, L.C., 2007. Uso de vinhaça e impactos nas propriedades do solo e lençol freático. Rev. Bras. Eng. Agr. Amb. 11 (11), 108-114.

Silva-Zacarin, E.C.M., Chauzat, M.P., Zeggane, S., Drajnudel, P., Schurr, F., Faucon, J.P., Malaspina, O., Engler, J.A., 2012. Protocol for optimization of histological, histochemical and immunohistochemical analyses of larval tissues: application in histopathology of honey bee. Curr. Microsc. Contrib. Adv. Sci. Technol. 1, 696-703.

Soto, M.A., Basso, J.B., Kiang C.H., 2017. Impacto da Fertirrigação da Cana-De-Açúcar por Vinhaça nas Propriedades Físicas, Químicas e Hidráulicas do Solo. In: Fontanetti, C.S., Bueno, O.C. (Org.). Cana-de-açúcar e seus impactos: uma visão acadêmica. Bauru, SP: Canal 6. pp. 103-124.

Soto, M.A.A., Basso, J.B., Kiang, C.H., Genuchten, M.T., 2015. Simulação de fluxo e transporte de íons de vinhaça através de vertente da formação rio claro. Águas Subterrâneas 29 (2), 162-174.

Toledo, M.C.M., 2000. Intemperismo e Formação do Solo. In: Teixeira, W., de Toledo, M.C.M., Fairchild, T.R., Taioli, F. (Eds.), Decifrando a Terra. Oficina de Textos, São Paulo, pp. 139-166.

Tsao, C.C., Campbell, J.E., Mena-Carrasco, M., Spak, S.N., Carmichael, G.R., Chen, Y. 2012. Increased Esti- mates of air-pollution emissions from Brazilian sugar-cane ethanol. Nat. Clim. Change 2, 53-57.

Van der Oost, R., Beyer, J., Vermeulen, N.P., 2003. Fish bioaccumulation and biomarkers in environmental risk assessment: a review. Environ. Toxicol. Pharmacol. 13 (2), 57-149.

Van der Voet, E., Lifset, R.J., Luo, L., 2010. Life-cycle assessment of biofuels, convergence and divergence. Biofuels 1, 435-449.

Varo, I., Serrano, R., Pitarch, E., Amat, F., Lopez, F.J., Navarro, J.C., 2002. Bioaccumulation of chlorpyrifos through an experimental food chain: study of protein HSP70 as biomarker of sublethal stress in fish. Arch. Environ. Contam. Toxicol. 42 (2), 229-235. 